\title{
ANALISIS INFORMASI ANATOMI PADA PEMERIKSAAN CT SCAN ANKLE JOINT MENGGUNAKAN PROTOKOL $C T$ ABDOMEN DAN PROTOKOL CT ANKLE JOINT DI INSTALASI RADIOLOGI RUMAH SAKIT GADING PLUIT JAKARTA
}

\section{ANALYSIS OF ANATOMICAL INFORMATION ON CT SCAN OF ANKLE JOINT EXAMINATION USING ABDOMEN CT PROTOCOL AND ANKLE JOINT CT PROTOCOL IN RADIOLOGY INSTALLATION OF GADING PLUIT JAKARTA HOSPITAL}

\author{
Gunawan Khairul Anam $^{1)}$, Bagus Abimanyu ${ }^{2)}$, Edy Susanto ${ }^{3)}$ \\ ${ }^{1,2,3)}$ Health Polytechnics of Semarang-Indonesia \\ e-mail: gunawankhairulanam@ymail.com
}

\begin{abstract}
Backgroud: In Radiology Installation of Gading Pluit Jakarta Hospital, CT Scan of the ankle joint uses abdomen CT protocol because it produces image quality that is considered to be able to diagnose and provide adequate information, although in Gading Pluit Jakarta Hospital there is a choice of CT protocol with Ultra High Resolution (UHR). The purpose of this study was to determine the difference of anatomical information on ankle joint CT scan between abdomen CT protocol and ankle joint CT protocol at Gading Pluit Jakarta Hospital and which protocol is better between UHR ankle protocol and abdomen protocol.

Methods: This type of this research was an experimental study. The study was conducted by performing two times of scanning with different protocols such as abdomen protocol and ankle joint protocol on ankle joint CT scan examination. The image was assessed by seven radiology physicians by viewing the information of the image. Data were analyzed statistically with Wilcoxon test.

Results: The results of this study showed that there was significant difference between abdomen protocol and UHR ankle joint protocol, with Wilcoxon p.value $=0,00(\mathrm{p}<0,05)$ and on ankle joint CT Scan examination, UHR ankle joint protocol was better than abdomen protocol so that the UHR ankle protocol was well applied in daily examination on CT scan of ankle joint.

Conclusion: There was difference between the abdomen CT protocol and ankle joint CT protocol (UHR) in Radiology Installation of Gading Pluit Jakarta Hospital. The ankle CT protocol (UHR) was better than the abdomen CT protocol on ankle joint CT scan examination in Radiology Installation of Gading Pluit Jakarta Hospital.
\end{abstract}

Keywords: CT scan of ankle joint, abdomen CT protocol, ankle joint CT protocol

\section{PENDAHULUAN}

Prosedur pemeriksaan Computed Tomography (CT) Scan menjadi sebuah pemeriksaan radiodiagnostik yang mampu menampilkan gambar bagian dalam tubuh manusia yang tidak terpengaruh oleh superposisi dari struktur anatomi yang berbeda. CT Scan dapat digunakan menilai struktur tulang, memeriksa kelainan paru, memeriksa pembuluh darah, koroner jantung, usus besar, saluran nafas dan struktur pembuluh darah (Rasad, 2005). Teknik pencitraan ini diperoleh dari seluruh informasi obyek yang diproyeksikan pada bidang dua dimensi dengan menggunakan teknik algoritma rekonstruksi gambar dan diolah dengan bantuan komputer.

Rekonstruksi algorithma berpengaruh langsung terhadap spatial resolusi. Penampakan dan karakteristik dari gambar CT-Scan tergantung dari kuatnya algorithma yang dipilih. Semakin tinggi rekonstruksi algorithma yang dipilih maka semakin tinggi resolusi gambar yang dihasilkan. Dengan adanya metode ini maka gambaran seperti tulang, soft tissue, dan jaringan-jaringan lain dapat dibedakan dengan jelas pada layar monitor. Filter tulang memiliki spatial resolusi yang paling baik dan filter jaringan lunak memiliki spatial resolusi yang lebih rendah. Pada beberapa pemeriksaan CT Scan sering kita dihadapkan untuk memilih beberapa pilihan rekonstruksi algoritma sesuai dengan kebutuhan pemeriksaan.

Komponen yang mempengaruhi kualitas gambar $C T$ Scan adalah spatial resolution, contrast resolution, noise dan artefact (Bushberg, 2002). Pada pencitraan CT Scan, slice thickness merupakan salah satu scan parameter yang cukup signifikan dalam menghasilkan kualitas gambar CT Scan yang optimal. Slice thickness yang tipis mempunyai spatial resolusi yang lebih baik, tetapi menghasilkan noise dan dosis radiasi yang besar (Muhler, 2005).

Filter atau lebih dikenal dengan Kernel dapat meningkatkan resolusi kontras tingkat tinggi atau dapat menghaluskan image dan mengurangi noise, juga meningkatkan resolusi kontras tingkat rendah. Semakin tinggi nilai image nosie, maka dapat dikatakan bahwa kualitas gambar CT-Scan akan semakin menurun. Dan sebaliknya, semakin rendah nilai image noise, maka kualitas gambar yang dihasilkan akan semakin baik (Seeram, 2001).

Protokol Ultra High Resolution (UHR) digunakan untuk menigkatkan spasial resolusi dan detail yang bagus. pembatasan yang digunakan adalah dengan menggunakan waktu scanning yang panjang secara signifikan ketika di 
gabungkan dengan menggunakan ukuran kolimator yang lebar. Batasan dosis dapat digunakan untuk membatasi dosis yang di terima pasien (Siemens medical 2012).

Penggunaan CT scan ankle joint biasanya menggunakan Ultra High Resolution (UHR) yang menghasilkan kualitas citra yang tinggi dan detail yang bagus, tetapi scantime yang diperlukan relatif lama dan pasien menerima dosis yang lebih besar (Siemens medical 2012). Protokol pemeriksaan CT Scan ankle atau UHR adalah KV 120, mAs 160, Rotation time (sec) 1,0 detik, Slice thickness $4 \mathrm{~mm}$, Pitch 1, Algortimbone + soft tissue adult body. Sedangkan di Rumah Sakit Gading Pluit Jakarta untuk CT Scan ankle joint menggunakan protokol $C T$ abdomen karena dapat menghasilkan kualitas citra yang dianggap sudah bisa menegakkan diagnosa dengan scan time yang singkat dan dosis radiasi yang diterima pasien lebih rendah, walaupun di Rumah Sakit Gading Pluit Jakarta ada pilihan protokol CT ankle joint dengan Ultra High Resolution (UHR).

Protokol pemeriksaan abdomen menurut Siemens medical (2012) adalah KV 120, mAs 200, Scan time 0,2 sec, Pitch 1,40, Slice thickness 2-4 mm, Algortim soft tissue dan osteo. Dengan asumsi scan time yang singkat dan dosis radiasi yang diterima pasien lebih rendah.

\section{METODE}

Jenis penelitian ini adalah penelitian eksperimental. Penelitian dilakukan dengan melakukan dua waktu scanning dengan protokol yang berbeda yakni protokol abdomen dan protokol ankle joint pada pemeriksan CT Scan ankle joint.

Pengaplikasian dua scanning dengan protokol yang berbeda tersebut dilakukan untuk melihat ada atau tidaknya perbedaan pada informasi anatomi dan atau untuk melihat scanning protokol yang mana yang lebih baik. Lokasi penelitian ini dilakukan di Rumah Sakit Gading Pluit Jakarta. Penelitian di lakukan pada bulan April sampai Juni 2016. Subyek dari penelitian ini adalah 7 dokter spesialis radiologi dari Rumah Sakit di wilayah Semarang dan RS Santo Borromeus Bandung sebagai responden dengan menggunakan kuesioner sebagai parameter penilaian.

Obyek dari penelitian ini adalah phantom ankle joint dan dilakukan CT Scan ankle joint dengan menggunakan protokol $C T$ abdomen dan protokol $C T$ ankle joint di Rumah Sakit Gading Pluit Jakarta.

Gambar CT Scan ankle joint yang menggunakan dua protokol yang berbeda yakni protokol $C T$ abdomen dan $C T$ ankle joint, kemudian di masukan kedalam aplikasi RadiAnt DICOM dan di print, kemudian diberikan kepada responden dalam hal ini adalah dokter spesialis radiologi untuk dinilai perbandingan informasi anatomi menggunakan kuisioner.

Kuisioner penilaian berisi pertanyaan tentang kriteria informasi anatomi CT Scan ankle joint yang menggunakan protokol yang berbeda yakni protokol $C T$ abdomen dan $C T$ ankle joint UHR dan dilihat dari kemampuan gambar menampilkan struktur anatomi dengan jelas dari tulang-tulang ankle joint. Penilaian jelas tidaknya struktur anatomi tersebut dibuat dalam tiga tingkatan penilain $(1-3)$ yaitu sangat jelas, jelas dan tidak jelas. Kuisioner mengacu pada penelitian dan jurnal sebelumnya yang sejenis, dan telah disetujui oleh seorang dokter spesialis radiologi.

Setelah mengumpulkan data berupa hasil analisa responden, maka langkah selanjutnya dalam analisa data terhadap data yang di peroleh dalam penelitian ini adalah melakukan pengujian dengan Wilcoxon Signed Rank Test dengan bantuan SPSS 20. Hasil uji tersebut dijadikan dasar untuk mengambil kesimpulan.

\section{HASIL}

Penelitian ini dilakukan pada pesawat Multi Slice Computer Tomografi (MSCT) 64 Slice merk SIEMENS di Instalasi Radiologi Rumah Sakit Gading Pluit Jakarta. Penulis melakukan observasi secara langsung dan pengambilan data dilakukan dengan cara melakukan 2 kali scanning menggunakan protokol abdomen dan protokol ankle joint Ultra High Resolution (UHR) pada organ phantom ankle joint. Kedua protokol tersebut memiliki parameter yang berbeda yang dapat menghasilkan citra atau gambar yang berbeda. Perbedaan tersebut terletak pada nilai mA, mAs Eff, Pitch, Rotation time, Kernel dan FOV.

Protokol ankle joint Ultra High Resolution (UHR) yang digunakan di Instalasi Radiologi Rumah Sakit Gading Pluit Jakarta adalah KV 120, mA 120, mAs 120, Rotation time (sec) 1,0 detik, Slice thickness $2 \mathrm{~mm}$, Pitch 0,85, Scan Delay $4 \mathrm{~s}$, Kernel U90 UHR bone + soft tissue adult body, FOV $150 \mathrm{~mm}$ dan Protokol abdomen adalah KV 120, mA 400, mAs 128 , Rotation time (sec) 0,5 detik, Pitch 1,40, Slice thickness $2 \mathrm{~mm}$, Scan Delay 4 s, Kernel B20f Smooth soft tissue dan osteo, FOV 317.

Hasil citra yang diperoleh, kemudian dibuat reformat tiga dimensi berupa irisan axial, coronal dan sagital dengan slice thickness sama-sama $2 \mathrm{~mm}$. Gambar hasil reformat axial, coronal dan sagital di copy dalam CD kemudian dimasukan kedalam aplikasi RadiAnt DICOM dan di print. Hasil dari citra tersebut dinilai oleh 7 orang responden dokter spesialis radiologi yang berada di Rumah Sakit Santo Borromeus Bandung 4 orang, Rumah Sakit Panti Wilasa Citarum 2 orang dan RSUD Kota Semarang 1 orang. Penulis menggunakan 7 orang responden, Karena responden sulit untuk ditemui dan pekerjaan mereka yang sangat banyak.

Perbandingan hasil citra CT Scan ankle joint dengan (A) protokol ankle UHR, (B) protokol abdomen, pada irisan axial, sagital dan coronal dapat dilihat pada gambar 1, 2, dan 3 .

Setelah hasil citra yang sudah di copy dalam CD kemudian dimasukan kedalam aplikasi RadiAnt DICOM dan diprint kemudian dinilai oleh ke 7 responden dalam bentuk Check List dilembar kuesioner untuk menilai informasi citra anatomi yang dapat diberikan pada tiap- tiap nilai pada organ ankle joint.

Tabel 1 menunjukan total nilai informasi citra dengan menggunakan protokol abdomen dan protokol ankle joint dari hasil kuisioner perbandingan informasi citra protokol abdomen dan protokol ankle joint. Dari data hasil kuisioner pada tabel 1 perbandingan informasi citra protokol abdomen dan protokol ankle joint, dapat dilihat bahwa jumlah pada kedua protokol memiliki nilai yang berbeda jauh. 

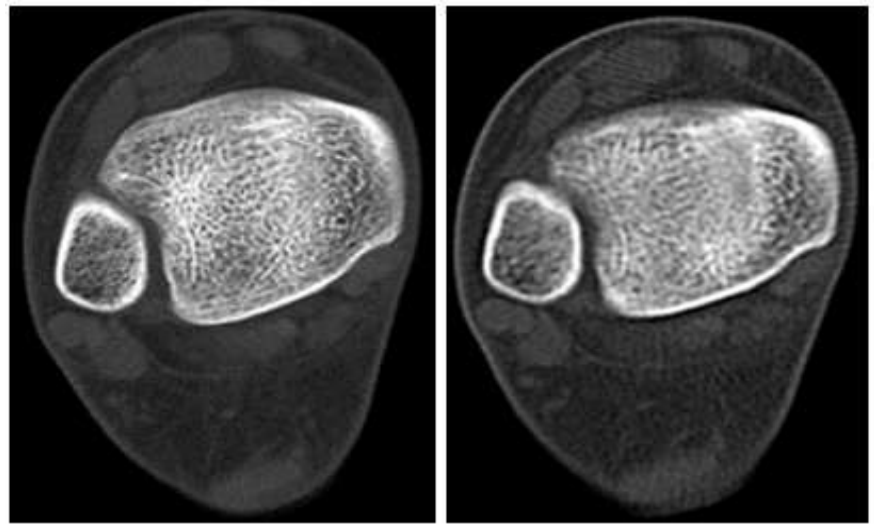

Gambar 1. Potongan Axial CT Scan ankle joint antara (A) protokol ankle UHR dan (B) protokol abdomen.
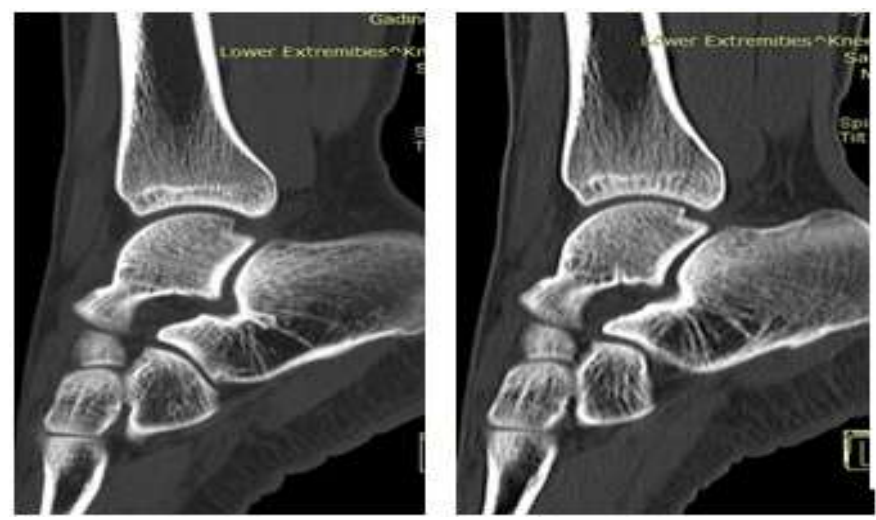

Gambar 2. Potongan Sagital CT Scan ankle joint antara (A) protokol ankle UHR dan (B) protokol Abdomen.
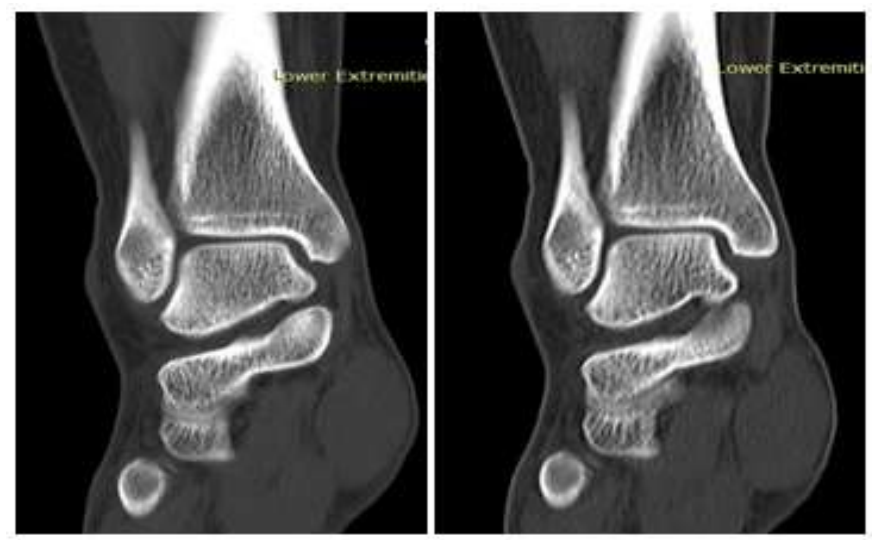

Gambar 3. Potongan Coronal CT Scan ankle joint antara protokol(A) ankle UHR dan (B) protokol abdomen.

Pada protokol ankle joint memiliki jumlah nilai 126 dan protokol abdomen memiliki jumlah nilai 82. Dengan demikian diartikan bahwa menggunakan protokol ankle lebih baik dibandingkan menggunakan protokol abdomen, dilihat dari jumlah nilai keseluruhan hasil kuisioner semua responden sehingga peneliti mendapatkan hasil deskriptif pada protokol mana yang lebih baik antara protokol abdomen dan protokol ankle joint (UHR).
Analisa protokol abdomen dan protokol ankle joint (UHR) pada pemeriksaan CT scan ankle joint berdasarkan uji normalitas data, data antara protokol ankle joint (UHR) dan protokol andomen yang diperoleh dilakukan uji normalitas data dengan menggunakan shapiro-wilk untuk mengetahui apakah data berdistribusi normal atau tidak normal. Setelah dilakukan uji normalitas, di dapatkan hasil nilai tidak signifikan pada protokol ankle joint (UHR) dengan nilai tidak signifikan < 0,00. Dari hasil uji normalitas data ini maka dapat diartikan bahwa data terdistribusi tidak normal, dilihat dari nilai tidak signifikan kurang dari $\mathrm{P}$ value $(0.00)$.

Untuk mengetahui ada tidaknya perbedaan antara protokol ankle joint (UHR) dan protokol abdomen pada pemeriksaan CT Scan ankle joint perlu dilakukan uji Wilcoxon. Tabel berikut menunjukan hasil analisis dari uji wilcoxon dari kuisioner pada masing-masing organ pada ankle joint. Hasil tersebut disajikan pada tabel 2.

Tabel 1. Hasil Kuisioner Perbandingan Informasi Citra Protokol Abdomen dan Protokol Ankle Joint

\begin{tabular}{ccc}
\hline Responden & $\begin{array}{c}\text { Citra A } \\
\text { Protokol Ankle }\end{array}$ & $\begin{array}{c}\text { Citra B } \\
\text { Protokol Abdomen }\end{array}$ \\
\hline 1 & 18 & 12 \\
2 & 18 & 6 \\
3 & 18 & 12 \\
4 & 18 & 12 \\
5 & 18 & 14 \\
6 & 18 & 12 \\
7 & 18 & 14 \\
\hline Jumlah & 126 & 82 \\
\hline
\end{tabular}

Tabel 2. Hasil Analisis Uji Wilcoxon dari Kuisioner masingmasing organ pada AnkleJoint.

\begin{tabular}{clc}
\multicolumn{3}{c}{ Variabel } \\
\hline NO & \multicolumn{1}{c}{ P Value } \\
\hline A & Distal Tibia & 0,034 \\
B & Distal Fibula & 0,034 \\
C & Post Process of Talus & 0,011 \\
D & Post Facet of Subtular Artic & 0,011 \\
E & Body of Calcaneus & 0,011 \\
F & Kortex Tulang & 0,011 \\
\hline
\end{tabular}

Pada Tabel 2 merupakan analisis uji Wilcoxon dari enam pertanyaan untuk masing-masing organ pada ankle joint secara keseluruhanperbandingan informasi citra pada protokol abdomen dan protokol ankle joint. Dari data tabel 2 tersebut, diketahui masing-masing organ sebagai berikut : perbandingan pada organ distal tibia antara kedua protokol mempunyai p.value $=0,034(\mathrm{p}<0,05)$. Ho ditolak: dengan demikian di artikan bahwa ada perbedaan secara signifikan pada organ distal tibia pada kedua citra dari kedua protokol.

Perbandingan pada organ distal fibula antara kedua protokol mempunyai p.value $=0,034(\mathrm{p}<0,05)$. Ho ditolak: dengan demikian di artikan bahwa ada perbedaan secara signifikan pada organ distal fibula pada kedua citra dari kedua protokol. Perbandingan pada organ post. Process of talus antara kedua protokol mempunyai p.value $=0,011(\mathrm{p}<0,05$ ). Ho ditolak: dengan demikian di artikan bahwa ada 
perbedaan secara signifikan pada organ post. process of talus pada kedua citra dari kedua protokol.

Perbandingan pada organ post. facet of subtalar artic antara kedua protokol mempunyai p.value $=0,011(\mathrm{p}<$ 0,05). Ho ditolak: dengan demikian di artikan bahwa ada perbedaan secara signifikan pada organ post. facet of subtalar artic pada kedua citra dari kedua protokol. Perbandingan pada organ body of calcaneus antara kedua protokol mempunyai p.value $=0,011(\mathrm{p}<0,05)$. Ho ditolak: dengan demikian di artikan bahwa ada perbedaan secara signifikan pada organ body of calcaneus pada kedua citra dari kedua protokol.

Perbandingan pada organ kortex tulang antara kedua protokol mempunyai $p$.value $=0,011(\mathrm{p}<0,05)$. Ho ditolak: dengan demikian di artikan bahwa ada perbedaan secara signifikan pada organ kortex tulang pada kedua citra dari kedua protokol. Dari hasil pengujian Wilcoxon dapat di ketahui juga, perbedaan informasi citra pada protokol abdomen dan protokol ankle joint secara keseluruhan. Sehingga dapat di artikan dan di analisa antara kedua protokol tersebut antara protokol abdomen dan protokol ankle joint. Hasil tersebut dapat dilihat pada tabel 3 yang merupakan analisa secara keseluruhan perbandingan informasi citra pada protokol abdomen dan protokol ankle joint. Dimana diketahui bahwa p.value yang dihasilkan adalah $0,000(\mathrm{p}<0,05)$ yang berarti Ho ditolak. Demikian dapat di artikan bahwa ada perbedaan secara signifikan antara protokol ankle joint dan protokol abdomen.

Tabel 3. Hasil Uji Wilcoxon Citra Protokol Abdomen dan Protokol Ankle Joint UHR Secara Keseluruhan Organ.

\begin{tabular}{cc}
\hline & Protokol Abdomen - Protokol Ankle \\
\hline $\mathrm{Z}$ & $-5,684$ \\
$\mathrm{P}$ Value & 0,000 \\
\hline
\end{tabular}

Hasil data kuisioner antara perbandingan informasi citra protokol abdomen dan protokol ankle joint, kemudian di lakukan pengujian dengan melakukan pengujian Wilcoxon signed rank test. Hasil dari pengujian tersebut disajikan pada tabel 4.

Tabel 4.Hasil penilaian Wilcoxon Signed Rank Test

\begin{tabular}{|c|c|c|c|}
\hline \multirow[b]{2}{*}{ NO } & \multirow[b]{2}{*}{ Jaringan } & \multicolumn{2}{|c|}{ Mean Ranks } \\
\hline & & $\begin{array}{c}\text { Protokol } \\
\text { Ankle (UHR) }\end{array}$ & $\begin{array}{l}\text { Protokol } \\
\text { Abdomen }\end{array}$ \\
\hline A & Distal Tibia & 3,00 & 0,00 \\
\hline B & Distal Fibula & 3,00 & 0,00 \\
\hline $\mathrm{C}$ & Post Process of Talus & 4,00 & 0,00 \\
\hline $\mathrm{D}$ & $\begin{array}{l}\text { Post Facet of Subtular } \\
\text { Artic }\end{array}$ & 4,00 & 0,00 \\
\hline $\mathrm{E}$ & Body of Calcaneus & 4,00 & 0,00 \\
\hline $\mathrm{F}$ & Kortex Tulang & 4,00 & 0,00 \\
\hline
\end{tabular}

Tabel 4 menjelaskan total hasil dari penilaian wilcoxon signed rank test menjelaskan pada informasi anatomi organ distal tibia, menyatakan organ distal tibia menggunakan protokol ankle joint lebih bagus dari pada menggunakan protokol abdomen, di lihat dari nilai mean rank. Mean rank protokol ankle joint pada organ disal tibia adalah 3,00 sedangkan mean rank protokol abdomen pada organ distal tibia adalah 0,00. Sehingga protokol ankle joint lebih bagus dari pada protokol abdomen karena mean rank protokol ankle joint pada organ distal tibia lebih tinggi dari pada mean rank protokol abdomen pada oran distal tibia.

Informasi anatomi organ distal fibula, menyatakan organ distal fibula menggunakan protokol ankle joint lebih bagus dari pada menggunakan protokol abdomen, di lihat dari nilai mean rank. Mean rank protokol ankle joint pada organ distal fibula adalah 3,00 sedangkan mean rank protokol abdomen pada organ distal fibula adalah 0,00 . Sehingga protokol ankle joint lebih bagus dari pada protokol abdomen karna mean rank protokol ankle joint pada organ distal fibula lebih tinggi dari pada mean rank protokol abdomen pada organ distal fibula.

Informasi anatomi organ post. process of talus, menyatakan organ post. Process of talus menggunakan protokol ankle joint lebih bagus dari pada menggunakan protokol abdomen, di lihat dari nilai mean rank. Mean rank protokol ankle joint pada organ post process of talus adalah 4,00 sedangkan mean rank protokol abdomen pada organ post process of talus adalah 0,00. Sehingga protokol ankle joint lebih bagus dari pada protokol abdomen karna mean rank protokol ankle joint pada organ post process of talus lebih tinggi dari pada mean rank protokol abdomen pada organ post process of talus.

Informasi anatomi organ post facet of subtalar artic, menyatakan organ post facet of subtalar artic menggunakan protokol ankle lebih bagus dari pada menggunakan protokol abdomen, di lihat dari nilai mean rank. Mean rank protokol ankle pada organ post facet of subtalar artic adalah 4,00 sedangkan mean rank protokol abdomen pada organ post facet of subtalar artic adalah 0,00. Sehingga protokol ankle lebih bagus dari pada protokol abdomen karna mean rank protokol ankle pada organ post facet of subtalar artic lebih tinggi dari pada mean rank protokol abdomen pada organ post facet of subtalar artic.

Informasi anatomi organ body of calcaneus, menyatakan organ body of calcaneus menggunakan protokol ankle joint lebih bagus dari pada menggunakan protokol abdomen, di lihat dari nilai mean rank. Mean rank protokol ankle joint pada organ body of calcaneus adalah 4,00 sedangkan mean rank protokol abdomen pada organ body of calcaneus adalah 0,00. Sehingga protokol ankle lebih bagus dari pada protokol abdomen karena mean rank protokol ankle pada organ body of calcaneus lebih tinggi dari pada mean rank protokol abdomen pada organ body of calcaneus.

Informasi anatomi organ kortex tulang, menyatakan organ kortex tulang menggunakan protokol ankle lebih informatif dari pada menggunakan protokol abdomen. di lihat dari nilai mean rank. Mean rank protokol ankle pada organ organ kortex tulang adalah 4,00 sedangkan mean rank protokol abdomen pada organ kortex tulang adalah 0,00 . Sehingga protokol ankle lebih bagus dari pada protokol abdomen karna mean rank protokol ankle pada organ kortex tulang lebih tinggi dari pada mean rank protokol abdomen pada organ kortex tulang. 
Tabel 5. Total hasil penilaian Wilcoxon Signed Rank Test Pada Nilai Keseluruhan Informasi Anatomi

\begin{tabular}{ll}
\hline & Mean \\
\hline Protokol Ankle & 3,00 \\
Protokol Abdomen & 1,95 \\
\hline
\end{tabular}

Dari hasil pengujian wilcoxon signed rank test dapat di ketahui juga nilai keseluruhan organ ankle joint. Keseluruhan organ informasi anatomi yang di dapat, dapat dilihat pada tabel 5 diketahui hasil informasi anatomi secara keseluruhan. Bahwa, dengan menggunakan protokol ankle lebih baik di bandingkan dengan protokol abdomen, karna nilai mean pada protokol ankle lebih tinggi dari pada nilai mean pada organ abdomen. Nilai mean pada protokol ankle secara keseluruhan organ adalah 3,00 dan nilai mean pada protokol abdomen secara keseluruhan organ adalah 1,95. Sehingga protokol ankle lebih bagus di bandingkan protokol abdomen.

\section{DISKUSI}

Pada hasil penelitian perbedaan informasi anatomi $C T$ Scan ankle joint antara protokol abdomen dan protokol ankle (UHR) oleh 7 orang responden dengan karakteristik informasi citra anatomi yang sama, diketahui bahwa antara kedua protokol yaitu protokol abdomen dan protokol ankle joint ada perbedaan yang bermakna antara dua penggunaan protokol tersebut, dapat dilihat pada tabel 6 berupa penilaian informasi citra anatomi $C T$ Scan ankle joint antara protokol abdomen dan protokol ankle (UHR) dengan hasil $p$ value $=0,000(\mathrm{p}<$ 0,05 ). Ho ditolak. Demikian dapat di artikan bahwa ada perbedaan secara signifikan antara protokol ankle joint dan protokol abdomen.

Perbedaan informasi citra anatomi CT Scan ankle joint antara protokol abdomen dan protokol ankle (UHR) disebabkan karena perbedaan protokol (pemilihan parameter). Perbedaan protokol (pemilihan parameter) tersebut berpengaruh terhadap visualisasi anatomi pada gambaran suatu organ. Hal ini sesuai dengan penjelasan dari Siemens medical (2012), menyatakan bahwa untuk penggunaan $C T$ Scan ankle biasanya menggunakan Ultra High Resolution (UHR) yang menghasilkan kualitas citra yang tinggi dan detail yang bagus. Penggunaan protokol (pemilihan parameter) yang baik dan tepat dapat berpengaruh terhadap visualisasi gambaran anatomi yang dihasilkan. Hal ini secara tidak langsung akan mempengaruhi pembacaan seorang radiologi dalam memberikan informasi citra anatomi.

Pada hasil penelitian protokol yang lebih baik antara protokol abdomen atau protokol ankle joint (UHR) oleh 7 orang responden dengan karakteristik penilaian informasi citra anatomi yang sama, diketahui bahwa dengan menggunakan protokol ankle menampilkan informasi anatomi yang lebih baik dari pada menggunakan protokol abdomen dapat dilihat pada tabel 8 berupa penilaian informasi citra anatomi CT Scan ankle joint antara protokol abdomen dan protokol ankle joint (UHR). Protokol ankle joint (UHR) dikatakan lebih baik dari pada protokol abdomen karena nilai rata-rata pada protokol ankle joint lebih tinggi dari pada nilai rata-rata pada protokol abdomen. Nilai rata-rata pada protokol ankle joint adalah 3,00 dan nilai rata-rata pada protokol abdomen adalah 1,95. Nilai rata-rata dari protokol ankle joint (UHR) 3,00 merupakan nilai tertinggi dari hasil uji analisis statistik. Dari nilai rata-rata dapat dilihat penilaian responden terhadap informasi citra anatomi yang diberikan.Semakin tinggi nilai rata-rata hasil analisis data dari chek list maka semakin tinggi pula penilaian responden atas informasi citra anatomi yang diberikan pada gambaran CT Scan Ankle Joint.

Pemilihan protokol yang baik pada pemeiksaan ankle joint berpengaruh terhadap parameter protokol yang digunakan. Protokol ankle joint (UHR)yang digunakan adalah KV 120, mA 12o, mAs 120, Rotation time (sec) 1,0 detik, Slice thickness $2 \mathrm{~mm}$, Pitch 0,85, Algortim bone + soft tissue adult body, FOV 150 dan Protokol abdomen adalah KV 120, mA 400 mAs 128, Rotation time (sec) 0,5 detik, Pitch 1,40, Slice thickness 2mm, FOV 317, Algortim soft tissue dan osteo.

Dari dua protokol tersebut antara protokol ankle joint dan protokol abdomen, yang membedakan protokol tersebut adalah mAs Eff, pitch dan FOV. Protokol abdomen menggunakan mAs 128 dan pada protokol ankle joint mAs 120, sehingga protokol abdomen memiliki densitas yang lebih tinggi pada pemeriksaan ankle joint. Semakin tinggi mAs semakin rendah noise dan densitas lebih tinggi (Bushberg, 2002). Namun hasil dari protokol ankle joint memiliki spasial resolusi yang lebih baik di bandingkan protokol abdomen menurut seeram (2001), hal ini dikarenakan protokol ankle joint memiliki pitch yang lebih rendah dan FOV lebih rendah dari pada protokol abdomen, FOV protokol ankle joint 150 dan pitch 0,85 sedangkan protokol abdomen FOV dan pitch 317 dan pitch 1,40. Tetapi pitch yang rendah dan FOV yang rendah dapat menghasilkan scan time yang lebih lama dan dosis yang diterima lebih banyak. Scan time yang dihasilkan pada protokol ankle joint adalah 30,31 s dan dosis yang diterima sebesar 10,62 mGy yang di lihat dari CTDI sedangkan untuk protokol abdomen scan time yan dihasilkan $8,87 \mathrm{~s}$ dan dosis yang diterima sebesar 6,81 mGy yang di lihat dari CTDI. Sedangkan untuk pemilihan kernel protokol ankle joint lebih bagus untuk melihat kondisi tulang karna kemapuan detail yang lebih jelas di bandingkan denggan kondisi tulang pada kernel protokol abdomen.

Menurut penulis, pada pemeriksaan CT Scan ankle joint lebih baik menggunakan protokol ankle joint(UHR) di karenakan pada hasil statistik pada tabel 8 menyatakan protokol ankle joint (UHR) lebih baik dari pada protokol abdomen yang di lihat dari nilai rata-rata keseluruhan. Nilai rata-rata protokol ankle joint adalah 3,00 sedangkan nilai ratarata protokol abdomen adalah 1,95 sehingga di artikan protokol ankle lebih baik dari pada protokol abdomen karena nilai rata-rata protokol ankle joint lebih tinggi dari pada nilai rata-rata protokol abdomen. Hal ini sesuai dengan penjelasan dari seeram (2012) bahwa dengan pitch, mAs dan FOV yang rendah dapat menghasilkan spasial resolusi yang lebih baik dari pada menggunakan pitch, mAs dan FOV tinggi. Protokol ankle joint (UHR) memiliki nilai pitch 0.85 , mAs 120 dan FOV 150 sedangkan protokol abdomen memiliki nilai pitch 1 , mAs 200 dan FOV 317. 


\section{SIMPULAN}

Terdapat perbedaan antara protokol ankle joint (UHR) dan protokol abdomen, sehingga Ha diterima dan dapat disimpulkan ada perbedaan informasi anatomi pada pemeriksaan CT Scan ankle joint antara protokol abdomen dan protokol ankle joint (UHR) di Instalasi Radiologi Rumah Sakit Gading Pluit Jakartadengan uji Wilcoxon p.value $=0,00$ $(\mathrm{p}<0,05)$.

Di Instalasi Radiologi Rumah Sakit Gading Pluit Jakarta protokol ankle joint (UHR) lebih baik di bandingkan protokol abdomen pada pemeriksaan CT Scan ankle joint dilihat dari nilai rata-rata keseluruhan. Nilai rata-rata protokol ankle joint adalah 3,00 sedangkan nilai rata-rata protokol abdomen adalah 1,95 sehingga di artikan protokol ankle joint lebih baik dari pada protokol abdomen karena nilai rata-rata protokol ankle joint lebih tinggi dari pada nilai rata-rata protokol abdomen.

\section{DAFTAR PUSTAKA}

Amarudin. 2007. ImageQuality. http://amarudin.multiply.com/jurnal. Tanggal di akses 2 Maret 2016

Bontrager, Kenneth L. 2010. Textbook of Positioning and Related Anatomy, Fifth Edition. CV. Mosby Company, St. Louis

Bushberg, J. T. 2002. The Essential Phisics of Medical Imaging, Second Edition. Lippincot Williams \& Wilkins, Philadelphia.

Bushong, C, Stewart. 2001. Computed Tomography. Mc Graw Hill Company, New York.

Jaengsri, N MSc. 2004. Protocol CT Technique. Radiology Departement OF Taleshin Hospital, Bangkok Thailand.

Lee, Chiu.C. 1995. Clinical Computed Tomography for The Tecnologist. Raven Press, New York, USA

Muhler, M. 2005. The influence of slice thickness on assessment of clavicle ossification in forensic age diagnostics. Berlin, Jerman.

Papp, Jeffrey, PhD,RT(R)(QM). 2006. Quality Management in The Imajing Sciences, third edition. Mosby Elsevier, Inc. Missoouri.

Rasad, Sjahriar, dkk. 2005. Radiologi Diagnostik, Edisi Kedua. Balai Penerbit FKUI, Jakarta.

Seeram, E. 2001. Computed Tomography: physical principles, clinical applications, and quality control, Second edition. WB Saunders Company, Philadelphia.

Siemens, Medical. 2012. Application Guide Somatom Sensation 64 Slices. Siemens AG, Germany.

Solomon, MA. 1986. CT Scannig of the Foot and Ankle.Normal Anatomy. Institut Radiologi Mallinckrodt, Washington University School of Medicine.

Sprawls, Perry. 1998. Physical Principlee of Medical imaging, Second Edition. Medical Physic Publishing, Medison, Wisconsin. 